\title{
"That Time of Month:" Premenstrual Dysphoric Disorder in the Criminal Law-Another Look
}

\author{
Rosanna Langer*
}

Department of Law \& Justice, Laurentian University, 935 Ramsey Lake Road, Sudbury ON P3E2C6, Canada

\begin{abstract}
This paper argues that women suffering from pre-menstrual dysphoric disorder (PMDD) ought to have available to them a range of legal defences that accurately reflect culpability. As PMDD focuses primarily on emotional mood and behavioural symptoms as opposed to physical manifestations of the premenstrual period, legal treatment of PMDD can be usefully compared to other "disordered states" that affect mental capacity, rationality and intent. Evolution of PMDD as a distinctive form of psychiatric disorder warrants a new consideration of the dual feminist concerns about the invisibility of women in criminal law theory and the undue labeling of all women. This article considers the application of criminal law defenses in light of newer research characterizing pre-menstrual mental disorder as a dynamic psychiatric and physiological state with shifting determinants that may be experienced differently over time. Ultimately, criminology must grapple with developing an account of women's criminality that reflects accurately women's lives lived within the sometimes overwhelming experience of biopsychosocial stressors. Reviewing PMDD in light of these concerns supports an enhanced understanding of the dynamics between women's mental health and culpability.
\end{abstract}

Keywords: Women, criminality, criminal defense, menstrual, psychiatry.

\section{INTRODUCTION}

This paper argues that women suffering from premenstrual dysphoric disorder (PMDD), an acute form of the more common premenstrual disorder (PMS), ought to have available to them a range of legal defences that accurately reflect culpability. A diagnosis of PMDD focuses primarily on the emotional mood and behavioural symptoms of the syndrome as opposed to the physical manifestations of the premenstrual period, therefore the legal treatment of PMDD can be compared to that of other organic disorders that affect mental capacity, rationality and intent ${ }^{1}$. Alternately, PMDD could be addressed as a situational biopsychosocial state paralleling judicial recognition of battered women's syndrome as a desperate response to a "perfect storm" of subjective and objective variables.

The evolution of PMDD as a distinctive form of psychiatric disorder will be examined and applied to a recent trend in some jurisdictions towards subjectivity

*Address corresponding to this author at the Department of Law \& Justice, Laurentian University, 935 Ramsey Lake Road, Sudbury ON P3E2C6, Canada; Tel: 705.675.1151.4108; E-mail: rlanger@laurentian.ca

${ }^{1}$ Most existing research, case law and literature refers to premenstrual syndrome (PMS) or premenstrual tension syndrome (PMT), with pre-menstrual dysphoric disorder (PMDD) being a relatively newly-labelled subset of those sufferers with exacerbated psychological, emotional and mood symptoms. When this article refers to PMDD, it therefore includes the symptomology and claims about PMS as well. In this discussion, commentary about severe PMS will be taken to denote the levels of functional psychological impairment sufficient to support the newer designation of PMDD. in criminal defenses ${ }^{2}$, a judicial narrowing of the sane automatism defence, and a substantially revised framework in Canada for the application of a "not criminally responsible by reason of mental disorder" or NCR-MD finding. These developments warrant a new consideration of the dual feminist concerns expressed about the invisibility of women in criminal law theory and the undue labeling of all women. Reviewing PMDD in light of these concerns supports an enhanced and more gender-responsive understanding of the dynamics between women's mental health and culpability.

\section{DIAGNOSTIC CRITERIA AND SYMPTOMS OF PMS AND PMDD}

The medical definition of PMS is "the recurrence of symptoms in the premenstruum with complete absence of symptoms in the postmenstruum." (Dalton 1986:145) However, it is not a simple matter to diagnose PMS, as over 150 symptoms have been associated with the syndrome. Data from a large number of recent studies support findings that women report a wide variety of symptoms. Authors contend that PMS symptoms can be divided into three categories: 1) physical symptoms including headaches, abdominal bloating, fatigue, breast tenderness, acne, lack of coordination, pelvic

${ }^{2}$ Canadian insanity jurisprudence, for example, mandates a subjective cognitive inquiry focused on the accused's capacity to evaluate whether her act is right or wrong in the particular circumstances in which it was committed; see $R v$. Chaulk (1990), 62 C.C.C.(3d) 193; R. v. Oommen (1994), 91 C.C.C.(3d) 8. For subjectivity in other defenses, see R.v. Lavalee, [1990] 1 S.C.R. 852 (battered woman syndrome as self-defense); R. v. Eyapaise (1993), 20 C.R. (4 ${ }^{\text {th }}$ ) (Alta Q.B.) (battered woman syndrome as self-defense rejected); $R$. $v$. Thibert, [1996] 1 S.C.R. 37 (verbal taunting by wife's lover as provocation); R. v. Hill, [1986] 1 S.C.R. 313 (homosexual assault as provocation). 
cramps, leg cramps, constipation, dizziness, joint pain, itching, nasal congestion and heart palpitations; 2) emotional symptoms including depression, angerhostility, anxiety-tension, guilt, rapid mood changes, feeling overwhelmed, panic, paranoia and suicidal thoughts; and 3) behavioural symptoms including, intolerance, being overly critical, restlessness, social isolation, cravings for sweets, increased use of alcohol, hysteria, confusion, forgetfulness, insomnia, physical violence, accident proneness, and decreased libido (Keye and Trunnell 1986).

The most troublesome symptoms are emotional and mood-related in nature. Most commonly reported are irritability, anxiety, tension, depression, and hostility and changes in patterns of normal social interaction including withdrawal from others. One large longitudinal study in a PMS Clinic found that during the luteal phase, a majority of patients reported feeling overwhelmed, anxious, tense and agitated; often ruminating obsessionally, suspicious and distrustful of others, more prone to misperceiving and misinterpreting interpersonal cues and attributing negative intentions to others. (Hammond 1988)

Somatic changes usually, but not always, accompany the emotional changes. The most common of the somatic complaints are breast tenderness, enlargement, or pain; swelling (of abdomen, ankles, fingers); back pain; and headache. Some additional items include: acne, changes in libido, hot flashes, changes in energy level (e.g., increased fatigue; hypomanic-like behavior), suicidal feelings; decrease in self-esteem; difficulty concentrating; mood swings; food cravings; impulsive behavior; crying spells; and insomnia. (Abplanalp 1985) Some research indicates that the premenstrual period is significantly correlated with accident proneness, susceptibility to alcohol and suicide attempts. (Chait 1986) Epileptic women have more seizures during this time of their cycle. (Abplanalp 1985) Abplanalp notes that up to recently, the issue of severity of symptoms was rarely investigated, but is now evaluated more routinely both with respect to intensity of the symptoms and their influence or impact on daily life.

Estimates of the incidence of PMS vary widely depending on the definition, ranging from $20 \%$ of all women requiring treatment, to $70-90 \%$ experiencing symptoms which they regard as tolerable, with a subset of $20-40 \%$ experiencing temporary physical or mental incapacitation. (Carney and Williams 1983-84) As well, women may be more ready to report symptoms as PMS rather than depression (Chait 1986).
"It is estimated that between two and ten percent of all women have symptoms of sufficient severity every month to interfere with their ability to function normally." (Apodaca and Fink 1984-85: 58) Within this group, a small number experience psychotic behavior or commit violent acts. They may experience irrational behavior, extreme depression, paranoia, aggressiveness, disorientation, rage, suicidal impulse, and nymphomania.

Dr. K. Dalton, a well-known pioneer in the field who has been researching PMS for over thirty years, and Director of the Premenstrual Syndrome Clinic at the University College Hospital in London England, observes that behavioral and psychological symptoms may include irritability, anger, confusion, depression, amnesia and uncontrollable impulses resulting in violence.(Carney and Williams 1985) She adds, "It is a diagnostic feature of PMS that incidents occurring while the woman is in her paramenstruum are spontaneous, irrational, and accompanied by loss of insight, confusion, amnesia, or loss of control." (Dalton 1986: 152) She has treated severe PMS with the hormone progesterone. But there is no biochemical test available which can determine such a deficiency or imbalance. As McSherry (1993: 296) observes, "It is misleading to reason from effectiveness of treatment to aetiology."

Researchers attribute PMS to various causes, including the psychological, social and biological, suggesting the involvement of the endocrine, neurological and immune systems as well as disordered mood and thought processes. Recent researchers characterize PMS as an imbalance of complex interactions of hormones, essential nutrients, and neurotransmitters, in combination with psychosocial stress. They observe that PMDD is also "a cluster of genetic, emotional, motivational, cognitive and behavioral changes that occur in regular association immediately prior to/or during the early menstrual days."(Pérez-Lopez et al. 2009:41) In addition, expectations, beliefs and cultural stereotypes about symptoms may be correlated psychodynamically with experiencing or heightening the experience of those symptoms. (Abplanalp 1988) Much of the frustration and skepticism surrounding PMS and the severity and complexity of PMDD may stem from the diversity of reported symptoms and the inability to forge a single causal explanation.

The biopsychosocial model aims to account for the psychological, social and cultural forces including experiences, beliefs, attitudes and personality of the 
patient, as influences on the development and clinical expressions of diseases. (Keye and Trunnell 1988; Grose 1988-89; Lennon and Rosenfield 1992) The model recognizes that psychophysiological responses to social factors may influence the expression and severity of illness. (Keye and Trunnell 1988) The American Psychiatric Association advances a model of situating mental health within social context and social stressors on Axis IV of the Diagnostic and Statistical Manual of Mental Disorders. Referring to psychosocial and environmental problems, they note that, "In addition to playing a role in the initiation or exacerbation of a mental disorder, psychosocial problems may also develop as a consequence of a person's psychopathology..."(American Psychiatric Association 2000: 31) These include problems within the primary support group, problems related to the person's social environment, educational or occupational problems, housing issues, economic difficulties, access to health care and problems related to interaction with the legal system. A multi-disciplinary approach to mental health makes sense of otherwise diverse symptomology: it is not difficult to understand how struggling with these types of problems in life may affect people differently, that those who are more vulnerable may find their impact on their wellbeing heightened, and that life stressors may themselves intensify existing mental disorders.

Even before it had a label, PMS has long been linked with women's irrationality and irritability. The fact that women bleed and regenerate in a monthly cycle is the biological root of universal and transhistorical myths about women's Otherness, power, weakness, uncleanliness, and association with dark spiritual forces and taboo. Early feminists argued against biological reductionism and worked to assert the normalcy of menstruation. (Shuttle and Redgrove 1978) Secondwave feminists advanced the social critique that gender is socially constructed; therefore medical and women's understandings of themselves would be similarly shaped by cultural menstrual myths and meanings. (Rodin 1992) Psychiatry itself has been criticized as a form of institutional control over women. (Caplan 1995) However, with this reclamation of the validity and normalcy of women's experiences was a glossing over of how biological and cultural factors entwined could result in genuine psychological infirmity. The pendulum has now swung towards a new reductionism whereby many psychological disorders are attributed to biological causes such as patterns in brain chemistry. Any balanced discussion of PMDD and its forensic implications must seek a delicate path among attribution, excuse and this notorious history of women's dismissal and exclusion from the determinations of mental health wellbeing.

In 1986 PMS was proposed for inclusion in the American Psychiatric Association revised third edition of the Diagnostic and Statistical Manual of Mental Disorders (DSM-III-R), but the APA instead used the term late luteal phase dysphoric disorder (LLPDD), which differed from PMS by a clear emphasis on mood and behavioral as opposed to physical symptoms. The diagnostic criteria for LLPDD included psychological disturbances that seriously interfere with work, ordinary social activities, or relationships, and occurring during the luteal phase, the week before, and ending within a few days after, the onset of menstruation. (Solomon 1995) Due to controversies around scientific validity and the over-medicalising and/or stigmatising women's health, LLPDD was listed in the DSM Appendix as a "proposed diagnostic category needing further study." (Solomon 1995: 577) By 1993, PMDD was introduced as a new disorder to be classified and a working group was established to decide on proposals whether and where to incorporate the disorder. It was listed as a possible form of "Depressive Disorder Not Otherwise Specified" with symptoms listed in the Appendix.

In spite of these developments in understanding premenstrual disorder, many women in the fields of psychiatry and psychology denounced the inclusion of a premenstrual affective disorder in the influential DSM. The principle objection is that it will pathologize women's normal cyclical changes in the same manner as historical cultural myths had been used to derogate women and impede women's full participation in public life. Methodological critiques point also to the fuzzy boundaries of the premenstrual period. Concern was expressed that LLPDD, the predecessor to PMDD, would simply be conflated with PMS, thereby labeling a broad swath of women as "mentally ill." (Severino 1988) An associated critique is that this diagnostic labeling occurs within a sexist society that already pathologizes and blames women, and that the mere availability of the diagnosis therefore legitimizes women's inferior status. (Caplan, McCurdy-Meyers and Gans 1992)

In contrast, women have said they felt relieved in the affirmation that they are experiencing "something real." (Caplan et al. 1992): 28-29)

Despite vigorous opposition from women's groups, the most recent version of the Diagnostic and 
Statistical Manual of Mental Disorders (DSM-IV) now includes premenstrual dysphoric disorder (PMDD) as a proposed form of depressive disorder. The DSM-IV distinguishes PMDD from the far more common premenstrual syndrome (PMS) in terms of the characteristic pattern of symptoms, their severity, and the resulting impairment. (Davidson 2000) Frequently, there is a history of prior mood and anxiety disorders and rarely, hallucinations and delusions have been described. The authors of the DSM observe that premenstrual mood and somatic symptoms also tend to run in families and are at least partially hereditary. (American Psychiatric Association 2000: 772-73) It is also noteworthy that there may be a premenstrual worsening of symptoms of various ongoing mental disorders that are known to be exacerbated during the premenstrual period. This disorder is distinguished from milder forms of PMS by requiring that the woman suffer from mood symptoms leading to some degree of functional impairment. At least five symptoms from a list of eleven must be present for a diagnosis of PMDD. ${ }^{3}$ These symptoms must have occurred during most of the menstrual cycles for the previous twelve months, with dysfunction occurring the week prior to menstruation and disappearing with the onset of menstruation.

The Mood Disorder Work Group for the DSM-V has recently reported their findings that the diagnosis, treatment and validation of the disorder have matured sufficiently to recommend premenstrual dysphoric disorder as a full category. (Epperson et al. 2012) The diagnostic criteria have been re-ordered slightly to

${ }^{3}$ Diagnostic Criteria For Premenstrual Dysphoric Disorder: In most menstrual cycles during the past year, five (or more) of the following symptoms were present for most of the time during the last week of the luteal phase, began to remit within a few days after the onset of the follicular phase, and were absent in the week postmenses, with at least one of the symptoms being either (1), (2), (3), or (4):

(1) markedly depressed mood, feelings of hopelessness, or self-depreciating thoughts

(2) marked anxiety, tension, feelings of being "keyed up," or "on edge"

(3) marked affective lability (e.g., feeling suddenly sad or tearful or increased sensitivity to rejection)

(4) persistent and marked anger or irritability or increased interpersonal conflicts

(5) decreased interest in usual activities (e.g., work, school, friends, hobbies)

(6) subjective sense of difficulty in concentrating

(7) lethargy, easy fatigability, or marked lack of energy

(8) marked change in appetite, overeating, or specific food cravings

(9) hypersomnia or insomnia

(10) a subjective sense of being overwhelmed or out-of-control

(11) other physical symptoms, such as breast tenderness or swelling, headaches, joint or muscle pain, a sensation of "bloating," weight gain.

Note: In menstruating females, the luteal phase corresponds to the period between ovulation and the onset of the menses, and the follicular phase begins with menses. In nonmenstruating females (e.g., those who have had a hysterectomy), the timing of luteal and follicular phases may require measurement of circulating reproductive hormones. (American Psychiatric Association 2000: 774) emphasize marked affective lability and irritability over depressed mood, but the basic description and criteria remain the same.

\section{PMS AND CRIME}

It has long been observed that menstruation may be associated with antisocial behaviour and increases in criminal, aggressive and rule-breaking behavior suggesting a lack of criminal responsibility. (Aplanalp 1985)

Dalton describes depression, irritability and temporary psychosis as the three most prevalent symptoms in women with patterns of criminal behavior (Dalton 1986; Brockington 1998):

in the depths of premenstrual depression, problems become insurmountable with the victim feeling hopeless, useless, ugly, lonely, unloved or guilty. Some sufferers indulge in irresponsible spending or the shoplifting of jewelry, dresses, or perfume, with no thought for the future... Other women suffering from this severe depression resort to suicide as a means of ending their misery. Still others smash windows and doors, attempt arson, or make prank phone calls. As a result of these activities, the victim of severe depression inadvertently may become involved in criminal proceedings. Irritability may appear as sudden mood swings accompanied by a complete loss of control. These episodes may involve yelling and shouting hysterically, breaking windows, hitting, or throwing whatever is nearest to hand as the irrepressible impulse takes over [....] PMS psychosis usually is short-lived, lasting only a day or two or even only hours. Nevertheless, visual or aural hallucinations, interminable reiterating thoughts, confused ideas, or feelings of persecution may trouble the sufferer during this period...The sufferer often experiences amnesia during these psychotic episodes, so that she may honestly state afterward that she cannot recall her actions.

Studies of women prisoners have shown that more women commit crimes during their premenstrual week than at any other times. (Ellis and Austin 1971; Dalton 1961; Dalton 1980; Chait 1986) 


\section{THE PROBLEMS OF “GENDERED”SYNDROME EVIDENCE}

Several factors impede the recognition of PMDD in the criminal law. One hurdle is that the disorder is not permanent in the sense normally applied to a disease of the mind, nor is it therefore temporary, but rather, episodic, cyclical and recurrent. Cyclical changes in mood may not be uniquely linked to the menstrual cycle. Furthermore, hormonal fluctuations may amplify or exacerbate underlying psychological conditions.(Mazure, Keita and Blehar 2002; Dixon and Dixon 2003-04) Many women who have premenstrual complaints (possibly as many as $40 \%$, based on a study of over two hundred subjects) also suffer from mood or anxiety disorders such as depression, bipolar disorder or panic disorder across the entire menstrual cycle.(Bailey and Cohen 1999) More recently the prevalence rate of premenstrual depression among women who suffer from depressive disorders has been estimated in several studies to be approximately sixtyfive percent. ${ }^{4}$ There is newer research proposing that PMS can be linked to serotonin deficiency which has also been consistently associated with depression. DeJong et al. (1985: 1359) state that "the results of several studies suggest that a special relationship exists between premenstrual syndromes and major psychiatric disorders, particularly affective illness."

Consideration must be given to the tendency for these disorders to be exacerbated during the premenstrual period. In re Jamie Lynn Irvin ${ }^{5}$ was a bizarre case of a violent and jealous woman who had repeatedly threatened and attacked her same-sex partner and previous partners. In psychological counseling, it had been disclosed that much of the defendant's violence had been associated with her menstrual periods. After a joint counseling session, Irvin forced her partner off the road, attacked her with a knife and took her hostage while the other woman pleaded to be taken to the hospital for treatment of her injuries. Irvin was convicted of felony assault. In addition, her now former partner commenced a civil suit seeking compensation for her injuries. The matter was resolved by settlement. Irvin then petitioned for bankruptcy seeking to discharge all her debts including the settlement judgment. The ex-partner argued that

\footnotetext{
${ }^{4}$ Testimony of expert witness, Dr. Laura Miller, Associate Head of the Department of Psychiatry, and Chief of the University of Illinois at Chicago Women's Mental Health Program, in Eli Lilly \& Co. v. Teva Pharms. USA, Inc., 2004 U.S. Dist. LEXIS 14724 at 19.

${ }^{5}$ In Re Jamie Lynn Irvin 31 B.R. 251; 1983 Bankr. LEXIS 6073; Bankr. L. Rep. (CCH) P69, 282.
}

the debt should not be discharged as it derived from a "willful and malicious injury by the debtor," provable by the creditor on clear and convincing evidence (an exemption provided by the statute). Irvin contended that the injuries were the result of uncontrollable conduct on her part, brought about by PMS. She further attested that she subsequently sought medical treatment and after adverse reactions to progesterone treatments, she underwent a hysterectomy, and had no further emotional difficulties since. However, other witnesses testified as to her extensive violence towards other partners in the past, with no menstrual correlation. She was also diagnosed with borderline personality disorder. The Bankruptcy Court observed a lack of general acceptance in the psychiatric community for the proposition that PMS is an explanation for inappropriate behaviour and that there is disagreement as to the cause of PMS and whether emotional instability leads to or results from PMS. It concluded that "Its acceptance as an explanation for improper conduct has not yet been established, either medically or legally."

Courts must assure themselves that psychological syndrome evidence is sufficiently reliable and valid. In Frye v. U.S. ${ }^{6}$ it was held that, in American federal law, evidence on a novel scientific theory must surpass the standard of general acceptance in order to admit the testimony of a qualified expert. The Supreme Court of Canada has adopted a broader view of the admission of expert testimony in criminal cases, which is held "to provide the judge and jury with a ready-made inference which the judge and jury, due to the technical nature of the facts, are unable to formulate." ${ }^{7}$ The Canadian Court has adopted the principle that in order for expert evidence to be admissible "the subject-matter of the inquiry must be such that ordinary people are unlikely to form a correct judgment about it, if unassisted by persons with special knowledge."8 Incorporation of premenstrual disorders into the Diagnostic and Statistical Manual of the American Psychiatric Association establishes this recognition.

This brings the discussion to the most significant concerns expressed with recognition of PMDD as a variant of depressive disorder. As noted earlier,

\footnotetext{
${ }^{6}$ Frye v. U.S. 293 F. 1013 (D.C.Cir.1923).

${ }^{7}$ R. v. Abbey, [1982] 2 S.C.R. 24

${ }^{8}$ Kelliher (Village of) v. Smith, [1931] S.C.R. 672.; See also R. v. Béland, [1987] 2 S.C.R. 398, at 415, where McIntyre J. speaks of an expert witness possessing "special knowledge and experience going beyond that of the trier of fact." See also R. v. Lavallee, [1990] 1 S.C.R. 852 (admission of expert evidence on battered women affirmed).
} 
inclusion of PMDD in the DSM was resisted by major women's mental health groups, including the American Psychiatric Association Committee on Women, the American Psychological Association Committee on Women, the Association of Women Psychiatrists and the National Coalition for Women's Mental Health (US) on the basis that its inclusion would stigmatize all women on the basis of innate female physiology. (Figert 1996) Zeedyk and Raitt (1999) observe that the misleading consensus presented by inclusion in the DSM masks the ongoing controversies over symptomology, causes and appropriate treatments, and reflects the powerful influence of medical fashions on the law. They express the foremost objection to recognizing PMDD in mental health and legal spheres, which is that a pathological account of women's impairment by PMS fits only too well with both historical and contemporary views about women's biology.

Historically and culturally, menstruating women have been subject to myths, taboos and social governance. (Delaney, Lupton and Toth 1988; Showalter 1993) Women's bodies are objectified and defined as deviant. (Mcarthur 1989) Women have been particularly subject to medicalizing discourses and medical discourse exerts a powerful social influence. Johnson and Kandrack (1995: 24) argue that that the syndromization of women's experiences through the intersection of medical and legal discourses "constructs the female body as problematic, requiring social regulation," thereby sustaining and legitimating systems of patriarchal capitalist subordination. In patriarchal societies, the assertion of "raging hormones" has provided an easy rationale for discrediting women. (Figert 1996; Laws, Hey and Eagan 1985) Feminist criminology has criticized extensively the predominance of deterministic and reductionist explanations for women's deviance and criminality based in female biology. (Smart 1986; Schur 1984; Boritch 1997; Carlen 2002; Balfour and Comack 2006) The acceptance of PMS as a diagnosis must be evaluated within these contexts. Therefore it is not surprising that incorporating a "PMS defence" into law would be met with trepidation and resistance by those who fear that it will validate the marginalization and stigmatization of women as unpredictable, irrational and irresponsible. For example, Huang (2002: 363) reasons:

The phenomenon has become trivialized by equating PMS with temperamental behavior. In fact, some might argue that PMS does not really exist, but is simply a way for women to excuse irrational behavior. Because of this sentiment, a feminist conflict emerges. Would the recognition of a premenstrual disorder be a validation of the suffering experienced by many women? Or would using PMS as a defense to plead insanity or diminished capacity simply further stigmatize women as being controlled by their hormones?

Yet if a woman lacks the basic intent, or mens rea to perform an act, or the act can be said to have been performed involuntarily, negating the actus reus, then the defendant's culpability has not been fully proved by the Crown, and she should not be convicted of committing a criminal offence. An Alberta woman charged with shoplifting argued PMS in her defense, which was disallowed; she was nevertheless acquitted because she proved she was irrational at the time of the incident and incapable of forming the intent to steal. Similarly, an Alberta provincial court judge sentenced a woman with PMS to three years probation on a charge of shoplifting and directed that she seek psychiatric care. (Fennell 1984)

Mcarthur (1989: 828) argues that "Both the female body and the female experience must be seen through her own particular, rather than peculiar, subjectivity." Others propose that the materiality of the female body be understood as mediated by culture, relationships, coping and distress as well as other subjective experiences. (Perz and Ussher 2006) Furthermore, in applying a biopsychosocial model of women's mental health, there is strong evidence that PMS may heighten and worsen other mood and behavioural disorders and exacerbate women's sense of powerlessness regarding their social situation. ${ }^{9}$ Taking into account that premenstrual changes can be both physically and mood-altering, that PMS is as much a dynamic process as a biological reality, and that there is a need to distinguish pathological from normal changes, PMDD may well result in mental states reducing or negating culpability. McSherry (1993: 313) points out that

\footnotetext{
${ }^{9}$ See e.g. Mother of six charged with child abuse, pleading guilty to a lesser charge of harassment, People v Santos (1982) 1 K04 6229 (NYC Crim. Ct. Kings County); woman crushing heavy drinking and habitually abusive boyfriend with her car after domestic altercation including him slapping and hitting her, $R \vee$ English (Nov. 10, 1981) unreported, Norwich Crown Ct.; after concealed pregnancy and adoption, young woman charged with murdering her mother, charge reduced to manslaughter, $R v$ Reynolds, [1988] Crim. L.R. 679 (C.A. Crim. Div.); woman living in considerable domestic unhappiness convicted of stabbing her common law spouse after hearing that he made advances on a neighbour, $R v$ Morris (1988), Crim. L.R. 256 (C.A. Crim. Div.); woman found guilty of careless driving and failure to stop at an accident after domestic argument Gibson or Thomas v Lowe, [1991] SCCR 943.
} 
distinguishing pathology from normality is not an unfamiliar task in criminal law, as it is not so different from determinations of knowledge or intent.

Chait (1986: 271) articulates the feminist dilemma:

PMS has been characterized as a doubleedged sword. If denied or treated lightly, researchers will ignore it, and women whose symptoms could be treated will continue to suffer. On the other hand, since the menstrual cycle is one of the few real biological differences between women and men, when we do acknowledge menstrual problems, they are alleged to be evidence of our biological inferiority.

At least some authors observe that recognizing severe PMS as an identifiable organic disorder, like hypoglycemia, epilepsy and sleep disturbances, guards against the reliance on menstrual myths and notions of female inferiority by treating it, in law, just as any other organic infirmity. (Carney and Williams 1983-84; D'Emilio 1985; Chait 1986) With inclusion in the DSMIV detailing relevant criteria to diagnose PMDD, both mental health and legal professionals now have the tools to distinguish the most serious manifestations of the disorder from those of minor impairment. In order to succeed in making a claim of significant impairment, a sufficient factual foundation may now be laid to show a causal connection between the defendant's symptoms and her conduct at the time of the alleged act. More stringent and advanced recent medical research will help to validate the legitimacy of the disorder in its effects on the cognition and culpability of a small cohort of women. In addition, undertaking more nuanced research into the biopsychosocial factors for PMS will help to assuage the concerns that PMS is applied as a label to dismiss women's collective anger at structural subordination and to assert social and political control over women. (Kendall 1991b)

The dilemma between affording a politicized defence to an individual PMDD defendant based on valid impairment of culpability and giving fuel to those would generalize to the gendered infirmity of all menstrual women must be resolved in the same fashion as all common law jurisprudence, on a careful consideration of the facts and medical evidence, and on a case by case basis. Some possible approaches are explored in the following sections.

\section{DIMINISHED RESPONSIBILITY}

The criminal law is based on the premise that people should be held responsible for their conduct. Insanity, as defined in criminal law, has been the chief exception. However, psychiatry has recognized no such bright line between soundness and unsoundness of mind. Wherever the line is drawn, there will be individuals who, due to their mental infirmity, are not wholly responsible for their actions. (Gannage 1981) The doctrine of diminished responsibility originated over one hundred years ago in Scotland, based on the concept of a "weakness of mind" and concomitant impairment of mental responsibility, ${ }^{10}$ and has been enshrined (in the case of homicides) in England in the Homicide Act, $1957 .{ }^{11}$ It provides for those cases of mental abnormality that border on insanity but do not quite reach it $^{12}$ to reduce a murder to manslaughter. Tracing a line of cases from 1963 to 1978, Gannage asserts that the doctrine of diminished responsibility also exists in Canadian case law (albeit unevenly), but not in so many words. He cites the examples of the Criminal Code infanticide provision which provides for a discretionary sentence of no more than five years, and case law admitting psychiatric evidence negating specific intent. PMDD arguably could fall within this doctrine in those cases where there is a combination of personality disorders insufficient to raise an insanity defence or where the defence is based on a combination of a severe PMS diagnosis and the known susceptibility of premenstrual women to alcohol sensitivity. Vulnerability to alcohol-induced violence will not likely be neutralized by a PMDD diagnosis however. In $R . \quad v$ Campbell, ${ }^{13}$ the appellant was convicted of murdering her husband and appealed three years later on the basis that she now had evidence to support an insanity or diminished responsibility defense. She and her husband had been drinking from pub to pub. She was seen to be yelling at him and appeared drunk. Many witnesses confirmed that she was aggressive and abusive when drunk, especially towards her husband. When they returned home, he fell asleep on a settee. She removed her wedding ring, placed it in his pocket, found a bottle of turpentine in the kitchen, poured it over him and set him on fire. Although initially denying it, eventually she admitted what she had done, saying she had intended

\footnotetext{
${ }^{10}$ See H.M. Advocate v. Dingwall, [1867] 4 S.L.R. 249 (Ct. Just.) as cited in Gannage (1981)

${ }_{11}^{11}$ Homicide Act, 19575 and 6 Eliz. 2, c.11 (U.K.).

${ }^{12}$ H.M. Advocate v. Savage, [1923] S.C.J. 49; R. v. Spriggs, [1958] 1 Q.B. 270 as cited in Gannage, (1981)

${ }^{13}$ R. v Campbell, [1999] Ct of Appeal (Crim. Div.)
} 
to "burn him a bit, not a lot, so he would feel it." She said she had not meant to kill him and that she had loved him. After the trial, the accused was examined by Dr. Dalton, who stated that PMS was a significant factor in her bizarre conduct on the night of the crime and caused diminished responsibility and confusion with inability to form a rational intent and appreciate the consequences of her actions that night. A second physician suggested that she suffered from mood abnormalities associated with a personality disorder that caused alcohol dependency. However, several other forensic psychiatrists testified that she was seriously aggressive at times when she was not premenstrual and that it was the contribution of the alcohol which was of significant importance. It was noted that the effect of alcohol on her personality was dramatic and observed by many; if there was a monthly pattern to her mood changes, this would have been apparent to her family. The Court dismissed the appeal, concluding that the new evidence was not sufficiently compelling to support a new defence based on diminished responsibility and that she was unlikely to succeed on retrial.

In 1980, Sandie Craddock was arrested for stabbing a fellow barmaid to death. ${ }^{14}$ Craddock had more than thirty prior convictions, mainly for criminal damage and assault, and had attempted suicide on multiple occasions. Each of these incidents had occurred at approximately the same time in her menstrual cycle and many involved inexplicably violent behaviour. As expert witness for the defence, Dr. Dalton diagnosed Craddock as suffering from premenstrual syndrome, and prescribed treatment with massive dosages of progesterone. Her expert testimony resulted in Craddock's murder charge being reduced to manslaughter. The medication stabilized Craddock's personality and she was released on probation contingent on continuing her treatment. However Craddock reappeared in court in 1982, having changed her name to Sandie Smith. ${ }^{15}$ She had been charged with two counts of threatening to kill a police officer, and one count of carrying an offensive weapon, a knife. Dr. Dalton testified that she had been progressively reducing Smith's medication when the offense occurred.

During her testimony, Dr. Dalton was asked whether Smith "would have done what she did, knowing what

\footnotetext{
${ }^{14} R$. v. Craddock (1981), 1 C.L. 49.

${ }^{15}$ R. v. Smith, No.1/A/82, [1982] Ct of Appeal (Crim Div.)
}

she was doing?" Dr. Dalton answered that, "She knew what she was doing, but she could not control herself. She lost her moral safeguards." The trial judge concluded, "It is quite clear from the doctor's evidence that this woman knew exactly what she was doing, intended to do it, but was led into doing it because the dark side of her nature appeared." ( $R$ v. Smith 1982) Smith was found guilty on all counts, but although it did not endorse PMS as a substantive defence, the trial court again recognized PMS as a mitigating factor and sentenced her to three years probation to ensure the monitoring of her conduct and the assurance of necessary treatment. The Court of Appeals upheld the sentence.

In another British case, Christine English deliberately pinned her boyfriend to a pole with her car and killed him. ${ }^{16}$ Dr. Dalton again testified as an expert at this trial and diagnosed English as suffering from "an extremely aggravated form of premenstrual physical condition." Further facts of the incident included the heavy-drinking and habitually abusive boyfriend slapping and punching her before leaving the car whereupon she "snapped." Not only do the facts raise the issue of provocation or another mental state of diminished responsibility such as battered woman syndrome, but as Kendall argues, ascribing her conduct to PMS risks trivializing the context in which it occurred. ${ }^{17}$ The court reduced the murder charge to "manslaughter due to diminished responsibility" and stated that English acted under exceptional circumstances. English was given a conditional discharge and driving suspension.

In R. v. Reynolds, ${ }^{18}$ the British Court of Appeals, Criminal Division, reduced a conviction and life sentence for murder to manslaughter and supervised probation. Reynolds, a young woman of 18 , who lived with her widowed mother, had had a concealed pregnancy and gave the baby up for adoption at birth. She said she did not tell her mother about the pregnancy because she felt that "she would not be able to cope with the knowledge and worry." Her mother found out about the pregnancy following a birth-related health complication a month later, but the accounts

\footnotetext{
${ }^{16} R$. v. English, unreported, Norwich Crown Ct Nov. 10, 1981, cited in Osborne (1989).

${ }^{17}$ Kendall makes a similar argument about Marsali Edwards, a London ON woman who seriously assaulted her estranged and violent husband with a weapon in 1989. PMS evidence was a significant factor in determining her sentences of three years probation so that she could receive proper treatment. Kendall (1991a).

${ }^{18}$ R. v. Reynolds, [1988] Crim L R 679 (C.A. Crim.Div.)
} 
indicate that she took it well. On the day of the homicide, the two had a minor argument about Reynolds taking a job in Wales. They went to bed in separate rooms, but Reynolds could not sleep and moved to a day-bed in her mother's room. Upon feeling "funny" and "unsettled," and referring to "all those months when I felt I was going to explode," she struck her mother repeatedly in the head with a hammer, causing her death. Claiming that she acted without thinking, she then opening several dresser drawers as if there was a burglary. She testified that, "I thought I could make myself believe it was someone else so that I wouldn't have to face it in my mind."

Despite expert evidence at trial of substantial impairment due to serious depression, Reynolds was convicted of murder, but appealed with an application to admit further medical evidence by both Dr. Dalton and another Crown-led consulting psychiatrist. On appeal, Dr. Dalton testified that this was a case of diminished responsibility, the cause being a conjunction of premenstrual syndrome and postnatal depression. With the endorsement of the Crown, and rather than ordering a re-trial, the Court set aside the murder conviction, explicitly accepting premenstrual syndrome as fitting within the defense of diminished capacity, and substituted a verdict of manslaughter. After fourteen months in custody, Reynolds was sentenced to probation with a condition of psychiatric supervision.

\section{PMDD AS INSANITY}

Despite its inclusion in the DSM-IV, it is difficult to argue for PMDD as a form of insanity under the M'Naughten rules because it is predominantly a physiological disorder rather than a disease or defect of the mind. Also, the PMDD defendant is only temporarily, albeit, cyclically chemically imbalanced, with normal behaviour for the remainder of the month. Pursuant to the M'Naughten rules, the defendant would have to argue that she lacked the cognitive capacity to comprehend the nature and quality of her actions or to distinguish right from wrong. The American Law Institute Model Penal Code ${ }^{19}$ established a more generous test in which a person is relieved from criminal responsibility who, at the time of the act, due to a mental disease or defect, lacked substantial capacity to appreciate the wrongfulness of her conduct or to conform her conduct to the law. As defined in the

\footnotetext{
${ }^{19}$ Model Penal Code, $\S 4.01,10$ U.L.A. $490-491$.
}

Code, however, insanity excludes mental diseases or defects that are manifested solely by repeated criminal or other anti-social behaviours. ${ }^{20}$ In addition, most American jurisdictions have legislatively narrowed the scope of the insanity provision making it difficult, if not impossible to assert PMDD as a conventional insanity plea. (Solomon 1995)

Both the American Bar Association and the American Psychiatric Association recommended the abolition of a third arm of the insanity defence addressing the inability to control one's own behaviour. Since 1984, the irresistible impulse test has been disallowed through statute in US Federal jurisdictions, but is still recognized in some form in seventeen states. ${ }^{21}$ The Canadian Criminal Code does not provide an exemption from criminal responsibility for someone incapable of controlling their volition. ${ }^{22}$ However, "irresistible impulse" may be taken into account in determining whether the accused was incapable of appreciating the nature of their actions or knowing that it was wrong. ${ }^{23}$ Some Australian jurisdictions also provide for incapacity to control one's actions due to mental disease or abnormality of mind. ${ }^{24}$

In those jurisdictions that retain an additional prong of the insanity defence providing for the inability to conform one's conduct to the law, the defendant may still be able to argue that her ability to control her conduct was substantially impaired. The "irresistible impulse test" provides a potential framework for describing the conduct of a PMDD defendant, because PMDD often results in compulsive behaviours that the defendants is unable to control, such as seizures, psychosis and kleptomania. (Apodaca and Fink 198485) In an early American case, Reid v. Florida Real Estate Commission, ${ }^{25}$ the petitioner was facing

\footnotetext{
${ }^{20}$ Model Penal Code, $\S 4.01$ (2) U.L.A. 490-491, as cited in D'Emilio (198485:580).

${ }^{21}$ After an attack on then President Ronald Reagan, the U.S. federal Insanity Defense Reform Act (1984) abolished the "irresistible impulse test" of the accused's capacity to control his [sic] behaviour. See (Simon and Aaronson 1988; Sadoff 1988).

${ }^{22}$ In R.v. Bergamin, [1996] A.J. No.965, 45 Alta. L.R. (3d) 367, Hunt J.A. stated, "An inability to control actions may give rise to a defence of involuntariness. But a mere failure to control actions is nothing more than an attempt to evade responsibility based upon the idea of an irresistible impulse, a defence that the law does not recognize." (at para 30.)

${ }^{23}$ See R. v. Berg, [2006] B.C.J. no. 1094 (B.C. Prov. Ct. Crim Div.) where accused, suffering from paranoid schizophrenia, acted on irresistible impulse without underlying rationality, to sexually assault and kidnap a 7 year old girl; see also, R. v. Wolfson (1965), 51 D.L.R. (2d) 428 (Alta. C.A.); R. v. Borg, [1969] S.C.R. 551, per Hall J. at 570-71; R. v. Abbey, [1982] 2 S.C.R. 24, at 38-39 as cited in R. v. Oommen, [1994] S.C.J. No. 60, [1994] 2 S.C.R. 507.

${ }^{24}$ Criminal Code Act 1983 (NT) s. 35; Criminal Code (QLD) s.27; Criminal Code 1924 (TAS) s. 16; Criminal Code 1913 (WA) s. 27, as cited in McSherry (1993).

${ }^{25}$ Reid v. Florida Real Estate Commission, 188 So. 2d 846; 1966 Fla. App. LEXIS 5132.
} 
suspension of her real estate broker's license as a consequence of shoplifting a beefsteak from the supermarket. She alleged that she had been going through a period of mental anguish, nervous discomfort, and emotional problems brought on by "the change of life" or menopause, and could not explain why she took the meat except that she was emotionally upset, distraught and under extremely high tension; she had already made several purchases in the store, "including the right number of steaks to be used for dinner." Her doctor testified that the theft was an isolated incident produced by her menopausal state and that, although she knew what she was doing was wrong, under the immediate stresses she was experiencing, she could not have helped her own actions. The Court cited authority for the proposition that Florida law (as it was at that time) may excuse a person who, while otherwise sane and competent, may nevertheless be incapable of forming a rational intent to do a particular act at a particular time. In quashing the Real Estate Commission's order, it further referred to the "irresistible impulse" branch of mental capacity which provided a ground for acquittal based on an inability to refrain from doing wrong.

\section{PMDD AS AUTOMATISM}

Another approach would be to characterize PMDDfuelled conduct as an involuntary act under a state of automatism, thereby negating either intent or actus reus, or both. Several authors have explored or proposed automatism as one potential avenue of defense for a woman committing a criminal act while suffering from severe PMS (Apodaca and Fink 198485; Carney and Williams 1983-84). An automaton acts involuntarily in an unconscious or semi-conscious state. Automatism has been categorized as both the product of a disease of the mind, therefore resulting in a finding of insanity, and alternately, as a product of another condition, whether physical or physiological, thereby providing a defense based in the absence of intentional action. It is usually accompanied by partial or complete amnesia of the episode. This unusual state was well-expressed by Lecourcière J. in $R . v K^{26}$ who described automatism as an "unconscious, involuntary act, where the mind does not go with what is being done." These states can be exhibited in a number of

\footnotetext{
${ }^{26} R . v K .(1971) 2$ OR 401; 3 CCC (2d) 84 (a case of psychological blow where $\mathrm{K}$, suffering severe obsessive-compulsive neurosis and depression, and on the verge of losing the family farm, was acquitted of the manslaughter of his wife after he learned through a telephone call that she was terminating their relationship.)
}

conditions, such as epilepsy, somnambulism, diabetes, arteriosclerosis, and in persons with otherwise healthy minds, and are therefore much broader than mental disorder or defect or "disease of the mind." "Non-insane automatism" (now, awkwardly, "non-mental disorder automatism") bridges the distinction between physical and mental diseases, since both may affect the defendant's conscious knowledge and therefore the ability to generate intention and to control her behaviour. (Apodaca and Fink 1984-85) It provides a complete defense resulting in acquittal.

The automatism jurisprudence remains highly controversial, in large part because it conflates a variety of distinct mental states, (Gault 2004; McSherry 1998) and also because of the dichotomy asserted between external and internal causes and their consequences for a finding of "disease of the mind." An internal cause is said to have its source in the psychological or emotional condition or in some organic pathology whereas an external factor such as a concussion or singular psychological blow is held to produce a transient disturbance of consciousness. (Arboleda-Florez 2002) This has resulted in the tenuous distinction between findings of hyperglycaemia or high blood sugar as internal, thus a "disease of the mind" 27 and hypoglycaemia as an excess of insulin, thus an 'external cause' of non-insane automatism. ${ }^{28}$ Development of the automatism jurisprudence has provided an increasingly narrow ground for those circumstances accepted as producing a state of nonmental disorder automatism, and classifying most internal traits, (ranging from parasomnia, epilepsy, arteriosclerosis and hyperglycaemia to depression and stress) as mental disorder automatism in order to provide for assessment of recurrence and risk.

The distinction between mental disorder and nonmental disorder automatism has been denounced by many in the psychiatric community on the basis that both may be the result of identifiable mental disorders.

\footnotetext{
${ }^{27} R \vee V$ Hennessy, [1989] W.L.R. 287 (high blood sugar level caused by unregulated diabetes held to be disease of the body affecting the mind).

${ }^{28}$ R. $v$ Bingham, [1991] Crim. L.R. 43 (diabetic charged with theft claimed hypoglycaemia; conviction quashed on appeal because trial judge failed to distinguish between hypo-and hyper-glycaemia; see also $R$. $v$ Clarke, [1972] 1 All E.R. 219 (diabetic charged with shoplifting, additional testimony that she suffered from depression; held on appeal that M'Naghten Rules do not apply to those who retain reason but do not apply it on moments of confusion or absentmindedness; conviction quashed; see also $R$.v Frost, [2003] BCJ (accused acquitted of criminal negligence causing death based on diabetic hypoglycaemia); R. v. Quick and Paddison, [1973] 3 All ER 397 (assault during insulin-induced hypoglycaemia held to be externally-produced therefore not 'disease of mind'); but see R. v. Parsons, [2006] NJ. No. 228 (Nfld. \& Lab. Prov. Ct.) (accused convicted of failing to stop at scene of accident causing death, automatism defense due to diabetic hypoglycaemia unsuccessful.)
} 
Dr. M. Mackay, on behalf of the Canadian Psychiatric Association, appeared before the Canadian House of Commons Sub-Committee on the Recodification of the General Part of the Criminal Code in their 1992 review of the Criminal Code, to state,

With respect to automatism, the law historically has been influenced by the Cartesian mind-body dichotomy. In this model, functional illness roughly correlates with diseases of the mind and organic illnesses with diseases of the brain or the body. Organic mental disorders are defined as those disorders causally related to demonstrable pathology. Functional mental disorders are those disorders in which there is no demonstrable pathology. However, with modern technology this distinction is disappearing.... Sophisticated biochemical markers offer the promise to identify illnesses previously considered functional as organic. As this continues, the brainmind dichotomy and the functional-organic distinction become less useful and less correct. $^{29}$

The leading case on automatism in Canada is Stone v. $R^{30}$ wherein the Supreme Court signaled a bold restatement of the substantive law. The accused admitted stabbing his wife over forty-seven times, disposing of her body, cleaning his truck, collecting a debt, selling a car and fleeing to Mexico. Mr. Stone claimed to have killed his wife while in an automatic state brought on by the psychological blow of her cruel and insulting words. While upholding the appellant's conviction for manslaughter, Bastarache, J., for the Supreme Court of Canada, took the occasion of the Stone appeal to clarify the availability and application of the automatism defence and establish a presumption of insanity that must be rebutted by the accused. First, the defendant must establish the evidentiary foundation of involuntariness on the balance of probabilities, typically calling expert psychiatric or psychological evidence to confirm. Secondly, the trial judge must determine

\footnotetext{
${ }^{29}$ CANADA, House of Commons, Sub-Committee on the Recodification of the General Part of the Criminal Code of the Standing Committee on Justice and the Solicitor General, House of Commons, Minutes of Proceedings and Evidence of the Sub-Committee on the recodification of the General Part of the Criminal Code of the Standing Committee on Justice and the Solicitor General, [Ottawa]: Queen's Printer for Canada, 1992-1993, Issue no. 6 (Chairperson: Blaine Thacker, M.P., Q.C.)

${ }^{30}$ Stone v. R. (1999), 2 S.C.R. 290 (S.C.C.)
}

whether the condition is mental disorder or non-mental disorder automatism, with the presumption being that of mental disorder. The trial judge must then determine whether the condition is a disease of the mind. This determination consists of two components: one, whether a normal person would have reacted similarly by entering an automatic state, and two, whether the condition presents a recurring danger to the public. If there is continuing danger, the condition should be found as a disease of the mind. If the condition is found not to be a disease of the mind, then the defence of non-mental disorder automatism can be considered. The significant dissent (by four of the nine judges) took the position that automatism is a sub-set of voluntariness, which must be proved by the Crown beyond reasonable doubt. No inference of voluntariness can be drawn if the accused leads credible evidence of unconsciousness, which is conceptually quite different from an insanity plea. Absent medical evidence supporting disease of the mind, the dissenters would still obligate the Crown to prove all elements of the offence including volition. The effect of Stone is to raise the evidentiary burden of the accused, broaden the definition of 'disease of the mind,' and severely narrow the ground for non-mental disorder automatism. ${ }^{31}$

In Canada therefore, the highest court has ruled to virtually extinguish the availability of any defence between culpability and insanity by requiring that a determination of "continuing danger" necessarily defaults to a verdict of NCR-MD. The application of this theory was recently explored in $R$. v Luedeke, ${ }^{32}$ where the accused fell asleep at a party after consuming several intoxicants and an extended period without sleep. A woman nearby him on the couch awoke to find him engaged in non-consensual sexual penetration of her; when confronted, he dazedly left the premises and went to his parents' house. When he woke up several hours later, he realized he was wearing a condom; with a vague sense that something had happened, he returned to the party premises, heard that a woman had alleged a sexual assault and turned himself in to police. At trial, Luedeke successfully advanced the defense of non-mental disorder automatism, arguing that his conduct was nonvolitional and not the exercise

\footnotetext{
${ }^{31}$ Healy comments trenchantly that "Stone widens the legal concept of mental disorder to vaporous indeterminacy, narrows insane automatism to picayune indeterminacy, and creates a "reasonable" violation of the presumption of innocence by imposing a legal burden on claims of sane automatism." (Healy 2000:92)

${ }^{32}$ R.v Luedeke, 2005 ONCJ 294, 35 C.R. (6) 205 (Ont. Ct. of Justice).
} 
of his conscious will. The sleep expert called as a witness stated that parasomnia is not a pathology or mental illness, but emerges out of normal sleep. Standard treatments include regular sleep hygiene, avoiding excess alcohol consumption, and use of the pharmaceutical drug clonazepam which reduces parasomniac activity by decreasing deep sleep.

In Luedeke, Otter, J. asserted that although somnambulism is not a disease of the mind, the court must still consider whether there is a continuing danger to the public because of the possibility of recurrence, especially of a serious crime of violence. In acquitting the defendant, the judge found this not to be the case. The acquittal was appealed by the Crown. ${ }^{33}$ The Ont. Court of Appeal observed that the cause of the automatism is important in characterizing its nature but that the definition of mental disorder is, in Canada, very broad, embracing any illness, disorder or abnormal condition that impairs the mind and its functioning, excluding self-induced and transitory states. ${ }^{34}$ Furthermore, the Criminal Code provisions governing dispositions of those accused but found not guilty by reason of mental disorder (NCR-MD) CC s.672.54, requires the absolute discharge of the individual, unless, on the evidence, they pose a significant threat to the public. ${ }^{35}$ The appeal in Luedeke was granted on the basis that the trial judge failed to appreciate the strong likelihood of the recurrence of precipitating factors, and whether, for policy reasons, (i.e. commission of a crime of violence) his conglitions should be classified as a disease of the mind. The case was sent back for a new trial wherein the accused was found not criminally responsible by reason of mental disorder and received an absolute discharge. $\mathrm{He}$ voluntarily entered into a peace bond, but the Crown did not apply for its renewal upon statutory expiry.

As an analytical tool, the 'continuing danger' theory asks whether the protection of the public dictates that the disordered mental state of the accused should be treated as a disease of the mind. The determination of 'NCR-MD, but still of potential continuing danger,' addresses the situation where a criminally accused may have committed her actions while in an automatistic state (thereby negativing both intent and

\footnotetext{
${ }^{33}$ R. v Luedeke, 2008 ONCA 716 (Ont. Ct of Appeal).

${ }^{34}$ at para 61 , quoting Dickson, J. in R. v. Cooper (1980), 51 C.C.C. 144 (S.C.C).

${ }^{35}$ Criminal Code, R.S.C. 1985 , c. C-46, s. 672.54 . In making a disposition following on a NCR-MD verdict, the court or review board is required to pursue the least restrictive and onerous alternative to the accused.
}

actus reus,) but there is nevertheless a possibility of the state re-occurring in such a way that may place others at significant risk. Canadian jurists have observed that the predictability of the automatistic state depends on the likelihood of recurrence of triggering events and that, "the greater the anticipated frequency of the trigger in the accused's life, the greater the risk posed to the public and, consequently, the more likely it is that the condition alleged by the accused is a disease of the mind." 36 This finding of "continuing danger" allows for a supervisory order notwithstanding the fact of absolute discharge.

Although the evidentiary burden of proving both involuntariness and reasonableness on the balance of probabilities sets an onerous burden on the accused, conceivably, the defendant committing a non-violent act, such as shoplifting, may still have the defense of non-mental disorder automatism available to her. For those where the act was violent and the defense succeeds in making out an automatism defense with NCR-MD as the verdict, court-ordered treatment orders for the PMDD suffering accused could follow a similar model as that applied in Luedecke. Problems would include i) the absence of a definitive treatment program to manage PMDD, ii) indeterminacy of the impact of the NCR-MD verdict, and iii) what to do if offender reoffends under similar circumstances?

\section{PMS AS MITIGATING MENTAL HEALTH FACTOR}

The most accessible approach in taking PMDD into account is that it should be recognized as a mitigating factor in sentencing. In circumstances where there is a connection between mental health issues and the offence, a more lenient disposition reflecting the accused's diminished responsibility is called for. ${ }^{37}$ Despite the groundbreaking work of Dr. K. Dalton treating PMS patients using massive dosages of progesterone, there is no definitive treatment for severe PMDD. Therefore incarcerating women who commit criminal acts as a consequence of their premenstrual state will have no positive effect on their condition. Indeed, Dr. Dalton notes that women often lose "good conduct" remissions of the full custodial sentence or accumulate further institutional violations because their pathological behaviour is exacerbated by stress and continues in the carceral environment and postrelease. (Dalton 1986)

\footnotetext{
${ }^{36}$ Bastarache, J. in Stone, supra, at 440.

${ }^{37}$ R. v. Dunne, [2011] ABPC 103 (Alta. Prov. Ct.)
} 
In R. $v$ Morris ${ }^{38}$ the defendant was living with a man in considerable domestic unhappiness. She was being treated by a psychiatrist and also for premenstrual tension. On the day of the assault, she had been told that he had made advances to a neighbour and this upset her greatly. While waiting for his return home, she consumed alcohol in combination with prescribed tranquilizers. After a brief and unsatisfactory exchange with him, she stabbed him in the chest with a knife as he lay in bed. The knife wound was a serious one requiring two weeks hospitalisation. Morris was charged and convicted of wounding with intent. Her sentence was reduced on the basis that the incident "followed upon a period of acute anxiety and tension," was unlikely to be repeated, and was "the outcome of an unusual concatenation of personal misfortunes.",39

In the case of R. v. Belcourt, ${ }^{40}$ the Alberta Court of Appeal held that while denunciation and deterrence are important principles of sentencing, they must be measured in light of the accused's mental condition. ${ }^{41}$ The Court cited C.C. Ruby, Sentencing (6th ed.)(2004) with approval, as follows:

It is, therefore, clear that a sentence can be reduced on psychiatric grounds in two instances: (1) when the mental illness contributed to or caused the commission of the offence; or (2) when the effect of imprisonment or any other penalty would be disproportionately severe because of the offender's mental illness. ... General deterrence should be given very little, if any, weight in a case where an offender is suffering from a mental disorder because such an offender is not an appropriate medium for making an example to others.

In the alternative, PMDD could be considered as a mitigating factor in sentencing, allowing for discharge on the charge, or for the courts to maintain supervision

\footnotetext{
${ }^{38}$ R. v Morris (1988), Crim L R 256 (C.A. Crim. Div.)

${ }^{39} R$ v Morris, ibid, at 259.

${ }^{40}$ R. v. Belcourt, 2010 ABCA 319, 490 A.R. 224 (Alta. C.A.) (sentence reduced due to appellant's highly entrenched delusional ideation contributing to her violent conduct).

${ }^{41}$ This principle has been applied variously in cases like $R$. v. Newby (1991), 84 Alta. L.R. (2d) 127 (Alta. C.A.) (exceptional suspended sentence for fraud based on respondent's fragile mental state); R. v. H.M.T., [2004] ABQB 743, 373 A.R. 197 (discharge conditional on continued psychiatric treatment and medication); R. v. Tremblay, [2006] ABCA 252, 401 A.R. 9 (Alta. C.A.) (sentence reduced conditional on continued treatment and medication); $R v$. Knoblauch, [2000] 2 S.C.R. 780 (conditional sentence to locked psychiatric ward affirmed.); R. v. Fraser, 2007 SKCA 113, (2007) 12 W.W.R. 615 (Sask. C.A.) (consideration of history of mental illness as mitigating factor did not result in demonstrably unfit sentence).
}

over a defendant who may still represent a danger to the public. However, if mitigation is not utilized as an opportunity for treatment, it serves only to reinforce the punishment of a defendant who is not morally blameworthy.

Some may argue that treating PMDD as a mitigating factor in sentencing gives the most flexibility with respect to supervisory treatment options. For example, Carney and Williams (1983-84:266) assert,

In Smith, the court explained that by recognizing PMS as a mitigating factor instead of a substantive defense, a court could retain control over an individual who may still be a danger to those around her. A substantive defense of PMS, on the other hand, would compel the courts to release a defendant unsupervised, with all of the consequent risks to society.

They do recognize however, that conviction and mitigation still are still inherently inadequate given that the defendant is morally blameless. However, it is contended here that, given the option to discharge the defendant or apply the "continuing danger" automatism jurisprudence in Canadian law, it is not the case that recognizing PMDD as a defense necessarily abdicates the ability to impose restrictions on the defendant.

\section{ACCOUNTABILITY}

If there is a group of women who commit acts in circumstances that should make them less blameworthy, then the criminal law should treat them differently. Legal recognition of PMDD as a mental disorder will not result in a "get out of jail free" card to every woman who menstruates: estimates of how many women suffer some symptoms of PMS are unrelated to those few who suffer the worst forms and fewer still who commit criminal actions. Furthermore, the spectre of fabricated claims of PMDD to excuse the actions of a defendant are not the only instance of frivolousness or fraudulent abuse of mental disorder evidence. $^{42}$

\footnotetext{
${ }^{42}$ See e.g. $R$ v. Teepell, [2009] O.J. No. 3988 (Ont. Ct. J.) (defendant convicted of sexual assault after unsuccessfully advancing defence of automatistic sexsomnia); R. v. Pottie, [2009] 2009 NSPC 57, (defendant convicted of driving while impaired, no foundation for defence of non-insane automatism); $R . v$. Bergamin, [1996] A.J. No. 965, 45 Alta. L.R. (3d) 367 (aggravated assault of seven year old son not non-insane automatism); Hensman v. Parsons, 235 Neb. 872; 458 N.W.2d 199; 1990 Neb. LEXIS 230, appellant argued unsuccessfully that PMS impaired her understanding of a contractual adoption agreement relinquishing custody of her two children to adoptive parents.
} 
Others argue that, assuming that PMS can be proved, in part because of documented recurrence over time, should the legal system not hold the defendant responsible for her behaviour when she ought reasonably to know that she manifests certain conduct such as violence on a monthly cycle? This presumption would have to exclude those, such as young women who are first experiencing their menstrual cycle and others, whose cyclical behaviour has been altered due to pregnancy, surgery, menopause or other hormonal changes. (Hosp 199192) Others would arguably have knowledge of their condition and its likelihood to impair their reasoning and actions, and therefore bear responsibility to selfpolice the effects of their symptoms. In Gibson or Thomas $v$ Lowe$^{43}$ the defendant was found guilty of careless driving and failure to stop after an accident and give her particulars to the other driver. As a consequence she was disqualified from driving for a period of six months. In her appeal, she pled that the sentence should be mitigated based on the fact that she had severe premenstrual tension, had a domestic argument before the accident, and had panicked and fled the scene. Her medical documentation verified that her premenstrual symptoms included anxiety, short temper, weakness, poor sleep, occasional stuttering, loss of control, aggression and irrationality. The appeal was allowed in part (driving suspension revoked but penalty points imposed) as the sheriff had failed to accord sufficient weight to the premenstrual syndrome evidence. Interestingly, the case reporter included a commentary to the question whether people should be allowed to drive at times when they are known to be likely to behave irrationally, and that it probably constitutes reckless driving to do so. PMS could therefore possibly aggravate culpability rather than mitigate it.

\section{CONCLUSION}

This article considers the application of criminal law defenses available primarily in Canada, but also in the United States and the United Kingdom, in light of newer research characterizing pre-menstrual mental disorder as a dynamic psychiatric and physiological state with shifting determinants that may be experienced differently over time. Ultimately, feminist criminology must grapple with developing an account of women's criminality that reflects accurately women's lives lived

${ }^{43}$ Gibson or Thomas v Lowe, [1991] SCCR 943. within the sometimes overwhelming experience of biopsychosocial stressors. It is dangerous to reduce women's criminal behaviours to a biological foundation, but equally wrong to dismiss genuine pathology as a ground for mitigating or absolving culpability.

\section{APPENDIX}

Canada, Criminal Code, R.S.C. 1985 , c. C-46.

Canada, House of Commons, Sub-Committee on the Recodification of the General Part of the Criminal Code of the Standing Committee on Justice and the Solicitor General, House of Commons, Minutes of Proceedings and Evidence of the Sub-Committee on the recodification of the General Part of the Criminal Code of the Standing Committee on Justice and the Solicitor General, [Ottawa]: Queen's Printer for Canada, 1992-1993, Issue no. 6 (Chairperson: Blaine Thacker, M.P., Q.C.)

Eli Lilly \& Co. v. Teva Pharms. USA, Inc., (2004 U.S. Dist. LEXIS 14724 [2004]).

Frye v. U.S. 293 F. 1013 (D.C.Cir.1923).

Gibson or Thomas v Lowe, [1991] SCCR 943.

H.M. Advocate v. Dingwall, [1867] 4 S.L.R. 249 (Ct. Just.)

H.M. Advocate v. Savage, [1923] S.C.J. 49.

Hensman v. Parsons, 235 Neb. 872; 458 N.W.2d 199; 1990 Neb. LEXIS 230 [1990].

Homicide Act, 19575 and 6 Eliz. 2, c.11 (U.K.).

In Re Jamie Lynn Irvin (31 B.R. 251; 1983 Bankr. LEXIS 6073 [1983])

Kelliher (Village of) v. Smith, [1931] S.C.R. 672.

People v Santos (1982) 1 K04 6229 (NYC Crim. Ct., Kings County).

R. v. Abbey, [1982] 2 S.C.R. 24.

R. v. Béland, [1987] 2 S.C.R. 398.

R. v. Belcourt, 2010 ABCA 319, 490 A.R. 224 (Alta. C.A.)

R. v. Berg, [2006] B.C.J. no. 1094 (B.C. Prov. Ct. Crim Div.).

R. v. Bergamin, [1996] A.J. No.965, 45 Alta. L.R. (3d) 367.

R. v. Bingham, [1991] Crim. L.R. 43.

R. v. Borg, [1969] S.C.R. 551.

R. v. Campbell, [1999] (C.A. Crim. Div.)

R. v. Chaulk (1990), 62 C.C.C.(3d) 193 (SCC). 
$R v$ Clarke, [1971] EWCA Crim 5 (CA Crim Div).

R. v. Craddock (1981), 1 C.L. 49.

R. v. Dunne, [2011] ABPC 103 (Alta. Prov. Ct.).

R. v. English (Nov. 10, 1981) unreported, Norwich Crown Ct.

R. v. Eyapaise (1993), 20 C.R. (4th) (Alta Q.B.)

R. v. Fraser, 2007 SKCA 113, (2007) 12 W.W.R. 615 (Sask.C.A.)

$R$ v. Frost, [2003] BCSC 1930.

$R v$ Hennessy, [1989] EWCA Crim 1 (CA Crim Div).

R. v. H.M.T., [2004] ABQB 743, 373 A.R. 197 (Alta. Q.B.).

R. v. Hill, [1986] 1 S.C.R. 313.

R. $v$ K. (1971) 2 OR 401; 3 CCC (2d) 84.

R. v. Knoblauch, [2000] 2 S.C.R. 780.

R. v. Lavalee, [1990] 1 S.C.R. 852.

R. v. Luedeke, 2005 ONCJ 294, 35 C.R. (6) 205 (Ont. Ct.J.).

R. v. Luedeke, 2008 ONCA 716 (Ont. Ct of Appeal).

R. v. Morris (1988), Crim. L.R. 256 (C.A. Crim. Div.)

R. v. Newby (1991), 84 Alta. L.R. (2d) 127 (Alta. C.A.)

R. v. Oommen, [1994] S.C.J. No. 60, [1994] 2 S.C.R. 507.

R. v. Parsons, [2006] NJ. No. 228 (Nfld. \& Lab. Prov. Ct.)

R. v. Pottie, [2009] 2009 NSPC 57 (NS Prov. Ct).

R. v. Quick and Paddison, [1973] 3 All ER 397.

R. v. Reynolds, [1988] Crim. L.R. 679 (C.A. Crim. Div.)

R. v. Smith, No.1/A/82, [1982] (C.A. Crim Div.)

R. v. Spriggs, [1958] 1 Q.B. 270.

R. v. Teepell, [2009] O.J. No. 3988 (Ont. Ct. J.).

R. v. Thibert, [1996] 1 S.C.R. 37.

R. v. Tremblay, [2006] ABCA 252, 401 A.R. 9 (Alta. C.A.)

R. v. Wolfson (1965), 51 D.L.R. (2d) 428 (Alta. C.A.)

Reid v. Florida Real Estate Commission, 188 So. 2d 846; 1966 Fla. App. LEXIS 5132 [1966].

Stone v. R. (1999), 2 S.C.R. 290 (S.C.C.).

United States, Model Penal Code, § 4.01, 10 U.L.A. 490-491.

\section{REFERENCES}

Abplanalp, Judith. 1985. "Premenstrual Syndrome." Behavioral Sciences \& the Law 3: 103-115.
Abplanalp, Judith. 1988. "Psychosocial Theories." Pp. 94-112 in The Premenstrual Syndrome, edited by W.R.Keye, Jr. Philadelphia: W.B. Saunders Co.

American Psychiatric Association. 2000. Diagnostic and Statistical Manual of Mental Disorders. 4ed. Text revision. (DSM-IVTR). Washington, DC: APA.

Apodaca, Lillian and Lori Fink. 1984-85. "Criminal Law: Premenstrual Syndrome in the Courts." Washburn Law Journal 24: 54-77.

Arboleda-Florez, Julio. 2002. "On Automatism: Editorial Review." Current Opinion in Psychiatry 15: 569-576.

Bailey, Jennie and Lee Cohen. 1999. "Prevalence of Mood and Anxiety Disorders in Women who Seek Treatment for Premenstrual Syndrome." Journal of Women's Health \& Gender-Based Medicine 8(9): 1181-1184. http://dx.doi.org/10.1089/jwh.1.1999.8.1181

Balfour, Gillian and Elizabeth Comack, eds. 2006. Criminalizing Women. Halifax, Fernwood Publishing.

Boritch, Helen. 1997. Fallen Women: Female Crime and Criminal Justice in Canada. Scarborough, ON: Nelson.

Brockington, lan. 1998. "Menstrual Psychosis." Archives of Womens Mental Health 1:3-13. http://dx.doi.org/10.1007/s007370050001

Caplan, Paula, Joan McCurdy-Meyers and Maureen Gans. 1992. "Should Premenstrual Syndrome Be Called a Psychiatric Abnormality?" Feminism and Psychology 2: 27-44. http://dx.doi.org/10.1177/0959353592021003

Caplan, Paula. 1995. They Say You're Crazy: How the World's Most Powerful Psychiatrists Decide Who's Normal. Reading, Mass.: Addison-Wesley Publishing.

Carlen, Pat, ed. 2002. Women and Punishment: The Struggle for Justice. Cullompton, UK: Willan.

Carney, Robert and Brian Williams. 1983-84. "Premenstrual Syndrome-A Criminal Defense." Notre Dame Law Review 59: 253-296.

Chait, Linda. 1986. "Premenstrual Syndrome and Our Sisters in Crime: A Feminist Dilemma." Women's Rights Law Reporter 9:267-293.

Christen, Brownlee. 2005. "Menstrual Cycle Changes the Brain." Science News 167:366-366. http://dx.doi.org/10.2307/4016419

D'Emilio, Joann. 1985. "Battered Women's Syndrome and Premenstrual Syndrome: A Comparison of Their Possible Use as Defences to Criminal Liability." St. John's Law Review 59: 558-587.

Dalton, Katharina. 1961. "Menstruation and Crime." (1961) British Medical Journal 2: 1752-1753. http://dx.doi.org/10.1136/bmj.2.5269.1752

Dalton, Katharina. 1980. "Cyclical Criminal Acts in Premenstrual Syndrome." Lancet 2(8203): 1070-1071. http://dx.doi.org/10.1016/S0140-6736(80)92286-2

Dalton, Katharina. 1986. "Premenstrual Syndrome." Hamline Law Review 9:143-154.

Davidson, Michael J. 2000. "Feminine Hormonal Defenses: Premenstrual Syndrome and Postpartum Psychosis." Army Law 5-18.

DeJong, Russell, David Rubinow, Roy-Bryce, Peter, M. Christine Hoban, Gay Grover and Robert Post. 1985. "Premenstrual Mood Disorder and Psychiatric Illness." 142 Am. J. Psychiatry 1359 (1985).

Delaney, Janice, Mary Jane Lupton and Emily Toth. 1988. The Curse: A Cultural History of Menstruation. Urbana: Univ. of Illinois Press.

Dixon Joe and Kim Dixon. 2003-04. "Gender -Specific Clinical Syndromes and Their Admissibility Under the Federal Rules of Evidence." American Journal of Trial Advocacy 27: 25.

Epperson, C. Neill, Meir Steiner, S. Ann Hartlage, Elias Ericksson, Peter Schmidt, lan Jones and Kimberly Yonkers. 2012. 
"Premenstrual Dysphoric Disorder: Evidence for a New Category for DSM-5." American Journal of Psychiatry 169:465-475.

Fennell, T. 1984. "Premenstrual Shoplifting: Two PMS IIIness Pleas bring Justice with Mercy," Alberta Report, May 07, p. 30.

Figert, Anne. 1996. Women and the Ownership of PMS: The Structuring of a Psychiatric Disorder. New York: Aldine de Gruyter.

Gannage, Mark. 1981. "The Defence of Diminished Responsibility in Canadian Law." Osgoode Hall Law Journal 19:301-320.

Gault, Stephen. 2004. "Dissociative State Automatism and Criminal Responsibility." Criminal Law Journal 28:329-350.

Grose, Nicole. 1988-89. "Premenstrual Dysphoric Disorder as a Mitigating Factor in Sentencing: Following the Lead of English Criminal Courts." Valparaiso University Law Review 33:201-230.

Hammond, D.Corydon. 1988. "The Psychosocial Consequences." Pp.128-141 in The Premenstrual Syndrome. Edited by W.R.Keye, Jr. Philadelphia: W.B. Saunders Co., 1988

Healy, Patrick. 2000. "Automatism Confined." McGill Law Journal 45: 87-106.

Hosp, Christina. 1991-92. "Has the PMS Defense Gained a Legitimate Toehold in Virginia Criminal Law? Commonwealth v. Richter." George Mason University Law Review 14:427446

Huang, Connie. 2002. "It's a Hormonal Thing: Premenstrual Syndrome and Postpartum Psychosis as Criminal Defense." Southern California. Review of Law \& Women's Studies 11:345-368.

Johnson, Kirsten and Mary Kandrack. 1995. "On the Medico-legal Appropriation of Menstrual Discourse: The Syndromization of Women's Experiences." Resources for Feminist Research 24: 23-31.

Kazan, Patricia. 1996-97. "Reasonableness, Gender Difference, and Self-Defense Law." Manitoba Law Journal 24:549-576.

Kendall, K. 1991. "Masking Violence Against Women: The Case of Premenstrual Syndrome." Canadian Woman Studies 12:1 17-20.

Kendall, Kathleen. 1991. "The Politics of Premenstrual Syndrome: Implications for Feminist Justice." Journal of Human Justice 2:77-98. http://dx.doi.org/10.1007/BF02636788

Keye, William R. and Eric Trunnell. 1986. "Premenstrual Syndrome-A Medical Perspective." Hamline Law Review 9:165-182.

William R. Keye and Eric Trunnell. 1988. "A Biopsychosocial Model," Pp. 201-219 in The Premenstrual Syndrome, edited by W.R.Keye, Jr. Philadelphia: W.B. Saunders Co.

Laws, Sophie, Valerie Hey and Andrea Eagan, eds. 1985. Seeing Red: The Politics of Premenstrual Tension. London: Hutchinson.

Lennon, Mary Clare and Sarah Rosenfield. 1992. "Women and Mental Health: The Interaction of Job and Family Conditions." Journal of Health and Social Behavior 33: 316327.

http://dx.doi.org/10.2307/2137311

Mazure, Caroline, Gwendolyn Keita and Mary Blehar. 2002. Summit on Women and Depression: Proceedings and
Recommendations. Washington, D.C.: American Psychological Association. available online at www.apa.org/pi/wpo/women\&depression.pdf accessed 09 July 2012.

Mcarthur, Karen. 1989. "Through Her Looking Glass: PMS on Trial." University of Toronto Faculty Law Review 47: 825-873.

McSherry, Bernadette. 1998. "Getting Away with Murder? Dissociative States and Criminal Responsibility." International Journal of Law and Psychiatry 21:163-176. http://dx.doi.org/10.1016/S0160-2527(98)00006-5

McSherry, Bernadette. 1993. "The Return of the Raging Hormones Theory: Premenstrual Syndrome, Postpartum Disorders and Criminal Responsibility." Sydney Law Review 15: 292-316.

Pérez-Lopez, Faustino, Peter Chedraui, Gonzales Pérez-Roncero, Maria López-Baina and José Cuadros-López. 2009. "Premenstrual Syndrome and Premenstrual Dysphoric Disorder: Symptoms and Cluster Influences." The Open Psychiatry Journal 3: 39-49. http://dx.doi.org/10.2174/1874354400903010039

Perz, Jannette and Jane Ussher. 2006. "Women's Experience of Premenstrual Syndrome: A Case of Silencing the Self." Journal of Reproductive and Infant Psychiatry 24:289-303. http://dx.doi.org/10.1080/02646830600973883

Rodin, Mare. 1992. "The Social Construction of Premenstrual Syndrome." Social Science and Medicine 35:49-56. http://dx.doi.org/10.1016/0277-9536(92)90118-A

Ruby, Clayton. 2004. Sentencing 6th ed. Markham: Butterworths.

Sadoff, Robert. 1988. "Political and Legal Perspectives." Pp. 15-26in The Premenstrual Syndrome, edited by W.R.Keye, Jr. Philadelphia: W.B. Saunders Co.

Sahni, Rajvinder. 1997. "Crossing The Line: R.v. Thibert and The Defence of Provocation." University of Toronto Faculty Law Review 55:143-151

Schneider, Elizabeth. 1992. "Describing and Changing: Women's Self-Defense Work and the Problem of Expert Testimony on Battering." Women's Rights Law Reporter 14: 213-242.

Schur, Edwin. 1984. Labeling Women Deviant: Gender, Stigma, and Social Control. Philadelphia: Temple Univ. Press.

Severino, Sally. 1988. "Letters to the Editor." American Journal of Psychiatry 143: 132-133.

Showalter, Elaine. 1993. The Female Malady, Women Madness and English Culture 1830-1980. London: Virago Press.

Shuttle, Penelope and Peter Redgrove. 1978. The Wise Wound: Menstruation and Everywoman. London: Victor Gollancz.

Simon, Rita and David Aaronson. 1988. The Insanity Defense: A Critical Assessment of Law and Policy in the Post-Hinckley Era. NY: Praeger.

Smart, Carol. 1986. Women, Crime and Criminology: A Feminist Critique. London: Routledge \& Kegan Paul.

Solomon, Lee. 1995. "Premenstrual Syndrome: The Debate Surrounding Criminal Defense." Maryland Law Review 54:571-600.

Zeedyk, M. Suzanne and Fiona Raitt. 1999. "Biology in the Courtroom: PMS in Legal Defences." Psychology Evolution and Gender 1:123-143.

Received on 11-07-2012

Accepted on 03-08-2012

Published on 03-10-2012

\section{DOl: http://dx.doi.org/10.6000/1929-4409.2012.01.3}

(c) 2012 Rosanna Langer; Licensee Lifescience Global.

This is an open access article licensed under the terms of the Creative Commons Attribution Non-Commercial License (http://creativecommons.org/licenses/by-nc/3.0/) which permits unrestricted, non-commercial use, distribution and reproduction in any medium, provided the work is properly cited. 